\title{
Comet Test in Saliva Leukocytes of Pre-School Children Exposed to Air Pollution in North Italy: The Respira Study
}

\author{
Claudia Zani, Elisabetta Ceretti, Ilaria Zerbini $@$, Gaia Claudia Viviana Viola, Francesco Donato, \\ Umberto Gelatti $(1)$ and Donatella Feretti * (i) \\ Department of Medical and Surgical Specialties, Radiological Sciences and Public Health, University of Brescia, \\ 11 Viale Europa, 25123 Brescia, Italy; claudia.zani@unibs.it (C.Z.); elisabetta.ceretti1@unibs.it (E.C.); \\ ilaria.zerbini@unibs.it (I.Z.); gaia.viola@unibs.it (G.C.V.V.); francesco.donato@unibs.it (F.D.); \\ umberto.gelatti@unibs.it (U.G.) \\ * Correspondence: donatella.feretti@unibs.it; Tel.: +39-030-3717691
}

Received: 1 April 2020; Accepted: 6 May 2020; Published: 8 May 2020

\begin{abstract}
Air pollution is a well-known problem for human health, especially for children living in highly polluted urban areas. This study aimed to assess the relationship between airborne pollutants concentration and biomarkers of DNA damage in the buccal mucosa cells of pre-school children. DNA damage was investigated with comet test in saliva leukocytes taken from sputum of 3- to 6-year-old children living in Brescia, Northern Italy, collected during two consecutive winter seasons (2012-2013). The daily levels of $\mathrm{PM} 10, \mathrm{PM} 2.5, \mathrm{NO}_{2}, \mathrm{CO}, \mathrm{SO}_{2}$, benzene and $\mathrm{O}_{3}$ in urban air were collected for the whole period. A questionnaire filled in by the children's parents was used to evaluate indoor and outdoor exposure. DNA damage in saliva leukocytes was evaluated in 152 children and the means of tail intensity and visual score as DNA damage were $6.2 \pm 4.3$ and $182.1 \pm 30.9$, respectively. No demographic and indoor or outdoor exposure variable was associated with the two measures of DNA damage. No significant association between air pollution and DNA damage in children's buccal leukocytes was found. In this study, the comet assay does not appear to be a valuable biomarker to detect DNA damage in children exposed to high levels of air pollutants, such as PM10, PM2.5 and $\mathrm{NO}_{2}$.
\end{abstract}

Keywords: children; early biological effects; DNA damage; comet assay; mucosa buccal cells; saliva leukocytes; urban air pollution

\section{Introduction}

Air pollution is a global problem: airborne or deposited pollutants can be found worldwide, from highly polluted to remote areas. Particulate matter (PM) has been widely investigated, especially in urban contexts, to determine its potential effects on human health [1-7]. Epidemiological studies have found a consistent association between exposure to airborne PM and the incidence and mortality for cardiovascular disease and lung cancer [8-11] and recently also with diabetes and other chronic diseases, possibly through oxidative stress and inflammation [12,13].

For a more complete evaluation of the risk to which people are exposed, it is important to evaluate the global effect of pollutants.

Short-term mutagenicity assays can be used to detect DNA damage resulting from exposure to mutagens. Their use is increasing for biomonitoring people, since they allow the detection of early effects of chronic exposure to toxic agents $[14,15]$, they are valuable for exposure to low doses and mixtures of toxicants, and they require a lower number of subjects and evaluation of objective parameters compared to traditional epidemiological studies [16]. 
Biomarkers of DNA damage can be investigated in various organs, tissues and body fluids, such as leukocytes or lymphocytes in peripheral blood [17-19]. However, cellular suspensions derived from target tissues are usually more appropriate. In particular, exfoliated buccal and nasal cells have been used in biological monitoring of people exposed to airborne pollutants as they are representative of epithelial respiratory tract cells and are easier to collect than those of other respiratory organs [20-26].

The single cell gel electrophoresis test (SCGE or comet assay) is a mutagenicity test that rapidly detects DNA damage in eukaryotic cells showing a very early, reversible DNA damage [27-30].

A significant association was found between high levels of urban pollution and DNA damage detected by the comet assay in human lymphocytes [18] and nasal mucosa cells in adults [25].

Children are more vulnerable to the adverse effects of air pollution due to their small body size, fast growth rate and relatively immature organs (lungs in particular), body functions [31], immune system and cell repair mechanisms [32,33]. They have higher levels of physical activity, spend more time outside and have a higher air intake than adults [34]. Moreover, some data suggest that genetic damage, caused by environmental pollutants, viruses or lifestyle factors, occurring early in life can increase the risk of carcinogenesis in adulthood [35].

Although the association between air pollution and respiratory symptoms and diseases has been shown consistently in children as well as adults, few data are available on biomarkers of early effect of air pollution in children [16,36-38].

This study is part of the Respira study (the Italian acronym for Rischio ESPosizione Inquinamento aRia Atmosferica) that aimed to assess the relationship between airborne pollutants concentration, urban air genotoxicity and biomarkers of DNA damage in the buccal mucosa cells of pre-school children $[20,39]$.

In this paper, we report the results of the comet test carried out in the saliva leukocytes of 3-to 6-year-old children living in a town with high levels of air pollutants. We also investigated the associations between biological data and the concentrations of some air pollutants and other exposure variables, including indoor pollutants.

\section{Materials and Methods}

The Respira study was described in detail in Ceretti et al., 2014 [20]. This part of the study concerns evaluation of DNA damage in saliva leukocytes of pre-school children living in Brescia, a town with heavy air pollution in Northern Italy. Briefly, we recruited the children attending 6 schools located in different areas of the town, characterized by different levels of traffic and presence of factories. We enrolled children aged 3-6 years, born in Italy and with European parents, without malignant tumours, who had not undergone radiotherapy or chemotherapy in the previous 12 months or X-rays in the previous 3 months. Only Caucasian children were enrolled in the study to limit the variability of response of cytogenetic markers, which may be also influenced by the ethnic group due to genetic polymorphisms and diet $[40,41]$.

DNA damage was investigated in saliva leukocytes taken from sputum: the children rinsed their mouths twice with mineral water and the mouthwashes were collected in tubes containing $25 \mathrm{~mL}$ of saline solution ( $\mathrm{NaCl} 0.9 \%)$ in order to obtain leukocytes for the comet assay [42].

The biological samples were collected in two consecutive winter seasons during or after a series of days with high levels of fine particulate matter (PM10 and PM2.5). The data about levels of ambient air pollutants were retrieved from the Regional Agency for Environmental Protection (ARPA) database. The daily levels of PM10, PM2.5, $\mathrm{NO}_{2}, \mathrm{CO}, \mathrm{SO}_{2}$, benzene and $\mathrm{O}_{3}$ from January to March of 2012 and 2013 were collected.

The project was approved by the Ethics Committee of the Local Health Authority of Brescia, Lombardy Region, on 10 August 2011, with the number of the general protocol 0112487.

The children's parents provided their written informed consent to participate in this study. All the data collected were treated in accordance with the Italian Privacy Law (196/2003). 
Children and their parents were interviewed on the characteristics of area of residence (e.g., traffic, factories), and children's possible exposure to indoor air pollution (stove, fireplace, parental smoking, etc.) using an ad hoc questionnaire.

\subsection{Comet Assay}

Cell suspension in saline solution were centrifuged for $10 \mathrm{~min}$ at $1100 \times g\left(\right.$ at $\left.4{ }^{\circ} \mathrm{C}\right)$ and the pellet was re-suspended in $1 \mathrm{~mL}$ of phosphate-buffered saline (PBS). Leukocyte viability was determined using the trypan blue technique; epithelial buccal cells present in the sputum samples were excluded. The comet assay was performed on buccal leukocytes, according to the method of Singh et al., 1988 [43] with minor modifications. PBS cell suspension was centrifuged for $4 \mathrm{~min}$ at $8700 \times g$, and the pellet was re-suspended in $200 \mu \mathrm{L}$ of LMA (low melting point agarose, $0.7 \%$ ) and layered onto pre-treated (NMA, normal melting point agarose, $1 \%$ ) slides. After overnight lysis $\left(4^{\circ} \mathrm{C}\right)$ in an alkaline buffer $(\mathrm{pH} 10)$ of cellular and nuclear membranes, the slides were placed in a horizontal electrophoresis box, allowed to unwind for $20 \mathrm{~min}$ in an electrophoretic alkaline buffer $(\mathrm{pH}>13)$ and then subjected to electrophoresis $\left(4^{\circ} \mathrm{C}\right)$ for $20 \mathrm{~min}$ by applying an electric field of $0.8 \mathrm{~V} / \mathrm{cm}$ and adjusting the current to $300 \mathrm{~mA}$. Lastly, the microgels were neutralized and fixed with absolute ethanol $\left(-20^{\circ} \mathrm{C}\right)$. To evaluate DNA damage, the slides were stained with ethidium bromide $(10 \mu \mathrm{g} / \mathrm{mL})$ and examined using a fluorescence microscope equipped with a high-sensitivity CCD (charge-coupled device) camera connected to a computerized image analysis system (Komet 5, Kinetic Imaging Ltd.). Computerized imaging was performed on coded slides using dedicated software which estimates damage parameters (e.g., tail length and tail intensity) by comet profile. DNA migration was evaluated also by visual score, a parameter derived from visual classification of the comets into four damage classes. Two hundred cells were analyzed for each subject (100 cells/slide, 2 slides per subject).

\subsection{Statistical Analysis}

The concentrations of air pollutants and DNA damage biomarkers are reported as means, standard deviations (SD), medians and percentages. We investigated the association between the visual score and tail intensity of the comet assay and the mean air pollutants levels one day, two days and one week before the biological sampling. Regression analysis was also performed with DNA damage as the dependent variable and the levels of air pollutants as predictors, adjusting for confounding factors (age, parents' smoking and education, traffic near home, and others). Two-tailed statistical tests were performed with $0.05 p$-value as the threshold for rejecting the null hypothesis. All the analyses were performed using the Stata TM 12.0 statistical package (Stata Statistical Software Release 12.0, 2012; Stata Corporation, College Station, TX, USA).

\section{Results}

A total of 222 children were enrolled, for 152 of which biological samples were adequate for the comet assay. None of the participants had asthma or other respiratory disorders investigated with the questionnaire.

The means of tail intensity and visual score were $6.2 \pm 4.3$ and $182.1 \pm 30.9$, respectively. No difference was observed in the comet test among children attending different schools or residing in different parts of the town.

In Table 1 the results of the comet test expressed as visual score and tail moment, according to demographic characteristics and children's exposure variables are reported. No demographic and exposure variable was associated with the two measures of DNA damage in saliva leukocytes. 
Table 1. Comet test results expressed as visual score and tail intensity according to demographic and indoor and outdoor environmental exposure variables.

\begin{tabular}{|c|c|c|c|c|c|}
\hline \multirow{2}{*}{$\begin{array}{l}\text { Demographic and Indoor and Outdoor } \\
\text { Environmental Exposure Variables }\end{array}$} & \multirow{2}{*}{$\mathrm{N}(\%)$} & \multicolumn{2}{|c|}{ Visual Score } & \multicolumn{2}{|c|}{ Tail Intensity \% } \\
\hline & & Mean \pm SD & Median & Mean \pm SD & Median \\
\hline \multicolumn{6}{|l|}{ Sex } \\
\hline M & $85(55.9)$ & $180.4 \pm 30.8$ & 179.0 & $6.1 \pm 4.6$ & 5.8 \\
\hline $\mathrm{F}$ & $67(44.1)$ & $184.2 \pm 31.2$ & 187.5 & $6.4 \pm 3.9$ & 7.0 \\
\hline \multicolumn{6}{|l|}{ Children's age } \\
\hline 3 years & $26(17.1)$ & $190.8 \pm 30.1$ & 196.2 & $7.1 \pm 3.8$ & 7.5 \\
\hline 4 years & $52(34.2)$ & $177.7 \pm 33.1$ & 171.8 & $5.5 \pm 4.6$ & 4.4 \\
\hline $5-6$ years & $74(48.7)$ & $182.1 \pm 29.4$ & 184.3 & $6.3 \pm 4.2$ & 6.8 \\
\hline \multicolumn{6}{|l|}{ Parents' education (at least one parent) } \\
\hline Primary school or less & $16(10.5)$ & $175.3 \pm 28.9$ & 175.4 & $5.3 \pm 3.7$ & 4.5 \\
\hline Secondary school & $47(30.9)$ & $184.8 \pm 29.1$ & 187.3 & $6.8 \pm 4.2$ & 7.4 \\
\hline College or university & 89 (58.6) & $181.9 \pm 32.3$ & 179.0 & $6.0 \pm 4.4$ & 5.4 \\
\hline \multicolumn{6}{|l|}{ Home characteristics } \\
\hline \multicolumn{6}{|l|}{ Traffic in the area } \\
\hline Heavy & $86(56.6)$ & $181.4 \pm 29.3$ & 182.5 & $6.0 \pm 4.0$ & 6.5 \\
\hline Moderate & $49(32.2)$ & $185.7 \pm 33.4$ & 180.0 & $6.8 \pm 4.8$ & 7.2 \\
\hline Very light & $17(11.2)$ & $175.2 \pm 32.0$ & 168.4 & $5.4 \pm 4.4$ & 4.1 \\
\hline \multicolumn{6}{|l|}{ Truck traffic in the area } \\
\hline Heavy & $27(18.0)$ & $171.6 \pm 26.5$ & 164.0 & $4.7 \pm 3.5$ & 3.3 \\
\hline Moderate & $59(39.3)$ & $180.6 \pm 27.6$ & 181.5 & $5.9 \pm 4.1$ & 6.3 \\
\hline Very light & $64(42.7)$ & $188.9 \pm 34.2$ & 190.9 & $7.2 \pm 4.6$ & 7.7 \\
\hline \multicolumn{6}{|l|}{ Indoor exposure } \\
\hline Gas stove in home & $7(4.6)$ & $172.9 \pm 18.9$ & 169.0 & $4.6 \pm 2.8$ & 4.6 \\
\hline Fireplace in home & $34(22.4)$ & $177.6 \pm 31.8$ & 179.5 & $5.6 \pm 4.0$ & 5.2 \\
\hline Presence of smokers in home & $24(15.8)$ & $179.2 \pm 31.4$ & 173.7 & $5.3 \pm 4.5$ & 3.7 \\
\hline \multicolumn{6}{|l|}{ School characteristics } \\
\hline \multicolumn{6}{|l|}{ Traffic in the area } \\
\hline Heavy & $87(58.0)$ & $178.0 \pm 29.1$ & 175.1 & $5.6 \pm 3.9$ & 5.3 \\
\hline Moderate & $54(36.0)$ & $187.0 \pm 33.0$ & 185.3 & $7.0 \pm 4.8$ & 7.2 \\
\hline Very light & $9(6.0)$ & $188.4 \pm 35.4$ & 198.0 & $6.7 \pm 4.4$ & 8.7 \\
\hline \multicolumn{6}{|l|}{ Truck traffic in the area } \\
\hline Heavy & $26(17.4)$ & $175.4 \pm 28.7$ & 169.7 & $4.9 \pm 3.7$ & 4.1 \\
\hline Moderate & $64(43.0)$ & $181.1 \pm 28.7$ & 183.7 & $6.1 \pm 4.0$ & 6.5 \\
\hline Very light & $59(39.6)$ & $186.4 \pm 34.3$ & 185.5 & $6.8 \pm 4.7$ & 7.4 \\
\hline \multicolumn{6}{|l|}{ Child's habits } \\
\hline \multicolumn{6}{|l|}{ Plays outdoors } \\
\hline Less than $1 \mathrm{~h}$ & $66(44.0)$ & $181.0 \pm 31.3$ & 179.2 & $6.2 \pm 4.4$ & 6.1 \\
\hline More than $1 \mathrm{~h}$ but less than $3 \mathrm{~h}$ & $57(38.0)$ & $182.9 \pm 28.9$ & 187.3 & $6.3 \pm 4.3$ & 6.6 \\
\hline $3 \mathrm{~h}$ or more & $27(18.0)$ & $184.4 \pm 35.4$ & 185.1 & $6.4 \pm 4.2$ & 7.3 \\
\hline \multicolumn{6}{|l|}{ Staying in the kitchen while meals are cooked } \\
\hline Never & $19(12.7)$ & $182.1 \pm 30.1$ & 181.5 & $5.8 \pm 4.1$ & 5.3 \\
\hline Sometimes & $97(64.6)$ & $180.1 \pm 29.5$ & 180.0 & $5.9 \pm 4.1$ & 6.0 \\
\hline Often/always & $34(22.7)$ & $186.7 \pm 35.9$ & 179.2 & $7.0 \pm 5.1$ & 6.5 \\
\hline \multicolumn{6}{|l|}{ Parents' smoking habits } \\
\hline Neither parent smokers & $97(64.2)$ & $183.9 \pm 32.5$ & 186.0 & $6.5 \pm 4.4$ & 7.0 \\
\hline Mother smoked during pregnancy & $32(21.0)$ & $185.3 \pm 23.7$ & 187.4 & $6.3 \pm 3.4$ & 6.7 \\
\hline Mother smoker & $27(17.8)$ & $178.0 \pm 23.3$ & 179.5 & $5.2 \pm 3.4$ & 4.8 \\
\hline Father smoker & $43(28.3)$ & $177.7 \pm 28.5$ & 173.2 & $5.5 \pm 4.1$ & 4.6 \\
\hline Both parents smokers & $38(25.2)$ & $178.6 \pm 22.1$ & 179.2 & $5.4 \pm 3.4$ & 4.7 \\
\hline
\end{tabular}


The results of linear regression analysis of the DNA damage, expressed as visual score and tail intensity, on the concentration of air pollutants (PM10, $\mathrm{PM} 2.5, \mathrm{NO}_{2}, \mathrm{SO}_{2}$, benzene and $\mathrm{O}_{3}$ ) at 1,2 and 7 days preceding biological sampling showed that the ozone level measured two days, but not one or 7 days, before the sampling was associated with an increase in DNA damage, which was statistically significant with the Wald test on the coefficient $(p=0.05)$. These results, considering the visual score data, are shown in Table 2.

Table 2. Coefficients of linear regressions of the DNA damage expressed as visual score on the concentration of air pollution at 1,2 days and 1 week preceding biological sampling computed for units of increase for each pollutant.

\begin{tabular}{cccc}
\hline Pollutant Levels in Days before Sampling & Coefficient & 95\% Confidence Interval & $p$-Value \\
\hline PM10 1 day & 0.035 & $-0.112 ; 0.183$ & 0.63 \\
PM10 2 days & 0.008 & $-0.179 ; 0.195$ & 0.93 \\
PM10 7 days & 0.085 & $-0.171 ; 0.341$ & 0.51 \\
PM2.5 1 day & -0.036 & $-0.211 ; 0.138$ & 0.67 \\
PM2.5 2 days & -0.053 & $-0.262 ; 0.155$ & 0.61 \\
PM2.5 7 days & 0.176 & $-0.166 ; 0.518$ & 0.31 \\
Benzene 1 day & -3.96 & $-8.947 ; 1.015$ & 0.11 \\
Benzene 2 days & -3.89 & $-9.018 ; 1.223$ & 0.13 \\
Benzene 7 days & -1.01 & $-7.336 ; 5.310$ & 0.72 \\
$\mathrm{NO}_{2}$ 1 day & -0.096 & $-0.449 ; 0.257$ & 0.59 \\
$\mathrm{NO}_{2}$ 2 days & -0.171 & $-0.639 ; 0.297$ & 0.47 \\
$\mathrm{NO}_{2}$ 7 days & 0.246 & $-0.304 ; 0.797$ & 0.37 \\
$\mathrm{SO}_{2}$ 1 day & -1.57 & $-3.095 ;-0.045$ & 0.04 \\
$\mathrm{SO}_{2}$ 2 days & -0.53 & $-2.487 ; 1.418$ & 0.58 \\
$\mathrm{SO}_{2}$ 7 days & 0.61 & $-1.460 ; 2.684$ & 0.58 \\
$\mathrm{O}_{3}$ 1 day & 0.27 & $-0.134 ; 0.690$ & 0.18 \\
$\mathrm{O}_{3}$ 2 days & 0.51 & $0.001 ; 1.019$ & 0.05 \\
$\mathrm{O}_{3}$ 7 days & 0.63 & $-0.215 ; 1.491$ & 0.14 \\
\hline
\end{tabular}

Figure 1 shows the scatterplots and the regression linear of the visual score by ozone concentration at each time point.

By contrast, the concentration of $\mathrm{SO}_{2}$ measured the day before the sampling showed a negative association with DNA damage $(p=0.04)$. No pattern was evident for the other air-quality parameters. 

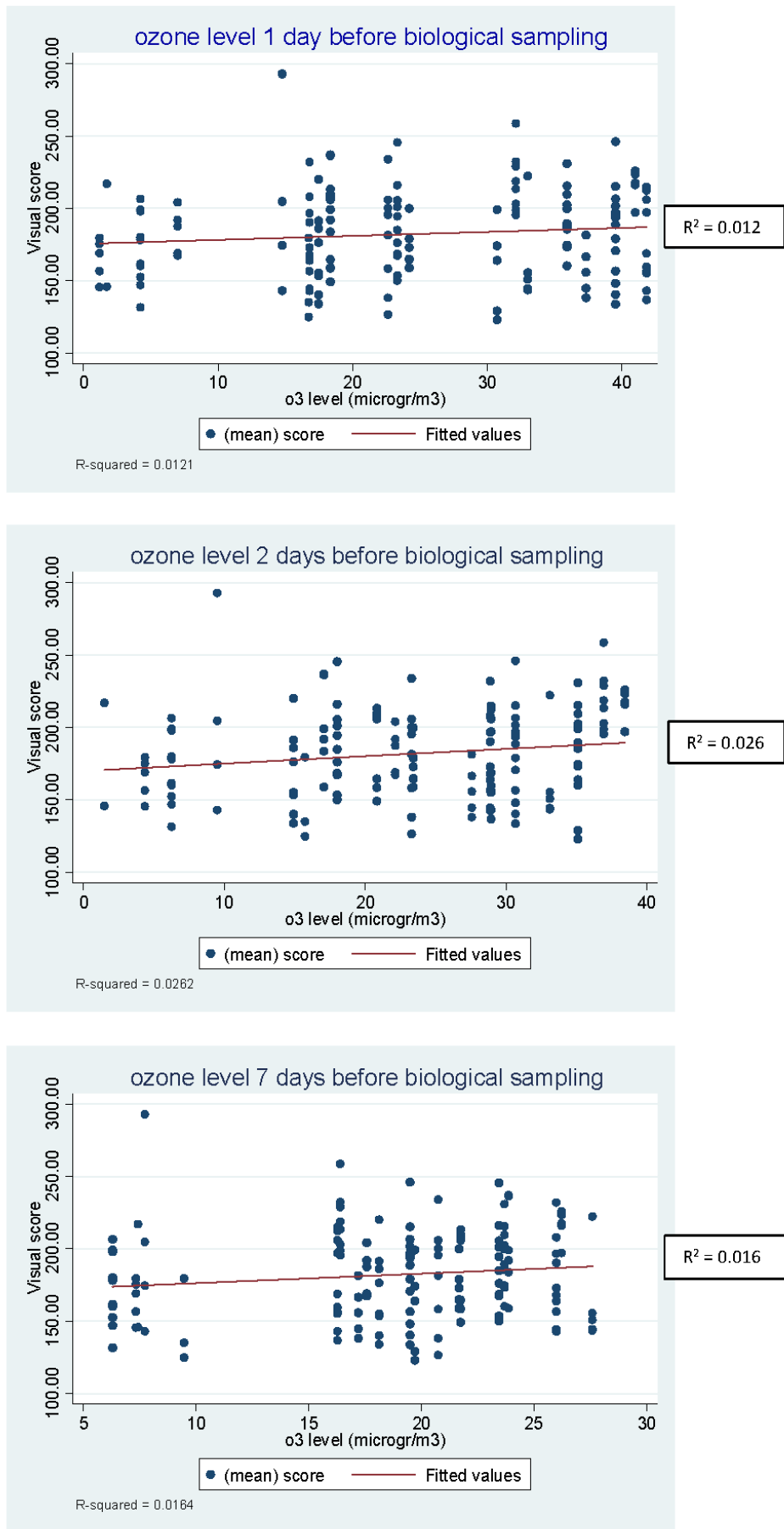

Figure 1. Scatterplots and the linear regression of the visual score by ozone concentration at 1, 2 and 7 days before biological sampling.

\section{Discussion}

This study focused on a biomarker of DNA damage in children because some data suggest that genetic damage occurring early in life may influence the risk of carcinogenesis and other chronic diseases in adulthood more than later damage. The use of a direct measure of biological effect, i.e., DNA breakages, which can be detected a long time before clinical disease develops can give us useful information about the substances to which children are exposed. This study did not show any association between DNA damage in buccal leukocytes of pre-school children and air pollutant levels 
at 1, 2 and 7 days before the sampling, apart from ozone: the mean ozone levels in the two days before the sampling was weakly associated with DNA damage, next to the limit of statistical significance, whereas the mean concentration of this pollutant in the day and in the 7 days preceding the sampling was not.

The comet test detects transient lesions produced directly by the mutagenic agent or indirectly by cellular repair mechanisms, and therefore is suitable to assess the effects of recent exposures. For this reason, we considered the concentration of the pollutants in the days immediately preceding the biological sampling in children.

Also the demographic variables and those concerning indoor pollution (passive smoking, parents' level of education, traffic next to children's school and home) were not significantly associated with comet visual score and tail intensity parameters. On the other hand, our indirect assessment of other children's exposures through a parental interview may have determined an imprecise estimate of the relationship with children's DNA damage.

Brescia is a town in North Italy with a high level of ambient air pollutants in winter, and during the period of biological sampling the concentrations of PM10 and PM2.5 were almost always over the European Union (EU) limit values for daily means. On the contrary, the concentration of other pollutants were always below the EU limits (data reported in Ceretti et al., 2014 [20]). In these children, a very high level of micronuclei (MN) frequency in exfoliated buccal cells was observed [20] which was associated with high levels of fine particulate matter. Therefore, these two biomarkers might be suitable to assess the effects of different pollutants: the comet test might reveal an oxidative damage possibly linked to the ozone concentration, according to others $[17,25]$ while the micronuclei test might reveal more stable damage induced by substances on fine particles, such as polycyclic aromatic hydrocarbons [38]. It is of note that we found no correlation between micronuclei frequency and DNA damage detected with the comet test in these children, suggesting that these biomarkers can detect independent events, as shown by other biomonitoring studies [44].

The concentration of ozone during the study period was not particularly high as this is a typically summer pollutant. Unfortunately, the study did not provide a collection of biological samples in children in periods with high concentration of oxidizing compounds such as ozone.

No difference was observed in DNA damage measured with comet test in salivary leukocytes of children attending schools located in various areas of the town, suggesting that residence or school area did not affect DNA damage, as observed for our study on micronuclei frequency [20]. Accordingly, we found a uniform distribution of pollutants in the urban air our town as well as mutagenicity of the particulate matter collected in different sites of the town in previous studies $[20,39,45]$.

Child exposure to air pollution is a matter of concern because of the well-known health effects of airborne pollutants and the relevance of early damage in childhood on the risk of developing chronic degenerative diseases in adulthood. Several studies have investigated the effects of outdoor and indoor airborne pollutants on children, using indirect measures of subject exposure, such as subjects report of vehicle traffic in the next-by streets, or direct measures of air pollutants but referred to a larger area, such as a whole town, and most of them have used the presence of symptoms or respiratory diseases as the effect measure, often based on self-referral. The Respira study, instead, used biomarkers of early biological effect, such as micronuclei formation [20] and DNA damage detected with the comet assay in children's buccal cells.

Various studies on adults exposed to high levels of air pollution using various biomarkers of biological effects in peripheral leukocytes found an association between air pollution exposure and DNA damage $[14,16]$. Although children are usually considered to be more susceptible to DNA damaging chemical compounds than adults [16], there is very little evidence that these or other early effect biomarkers are related to urban air pollution exposure in children as well in adults at present [44,46-54].

The results of this research are not fully comparable with other studies because we included very young children and used different comet parameters (e.g., tail intensity, tail length, olive tail moment). 
Moreover, little data are available in the buccal cells of very young children. Nevertheless, the mean value for tail intensity found in our children was $6.2 \pm 4.3$, that is of the same order of magnitude as that observed in other studies in peripheral lymphocytes of children and adolescents living in lowand high-polluted Brazilian urban areas [44,54]. The correlation between chromosomal damage in peripheral lymphocytes and that in buccal cells [55] makes salivary leukocytes a valid alternative to blood lymphocytes.

We observed a weak linear relationship between ozone concentration and DNA damage through the comet test, which is difficult to interpret because of the low levels of this pollutant in winter in our area. However, the lack of sampling collection in summer, when ozone levels are high, does not allow us to draw a definite conclusion on this point. The absence of data for summer, when most air pollutants except ozone are lower than in winter, and the lack of a control group of subjects living in a less polluted area are a limitation of this study. Another limitation of the study is that biological sampling was carried out only once for each child, in line with other studies investigating the association between air pollution exposure and biological damage in the general population $[25,26,44,46,54]$. The sampling repetition at different times could provide useful information on the variability of the relationship between cellular damage and air pollution. Nevertheless, the strength of this study is that DNA damage in buccal leukocytes was analysed in 152 children living in the town and exposed to high levels of air pollutants in winter which is a not negligible number when compared to present research with this biomarker $[44,46,48,50,52]$.

New and interesting approaches that use exhaled breath, a non-invasive technique now used above all for diagnostic purposes, could also have applications in vitro tests and be combined with other biomarkers to evaluate the risks in children of future respiratory diseases [56-59]. The non-invasiveness is an important aspect in preventive studies involving children. Leukocytes from saliva as well as epithelial cells of the oral mucosa, representative of epithelial respiratory tract cells, were easy to collect, and especially in the pediatric population, a collection method that is more acceptable to children and their parents which favored participation in the study. Furthermore, the correlation between chromosomal damage in peripheral lymphocytes and that in buccal cells makes salivary leukocytes a valid alternative to blood lymphocytes.

\section{Conclusions}

In this study no significant association between air pollution and DNA damage in children's saliva leukocytes was found. The comet test does not appear to be a valuable biomarker to detect DNA damage in children exposed to high levels of air pollutants, such as PM10, PM2.5 and $\mathrm{NO}_{2}$.

Author Contributions: Conceptualization, E.C., F.D., U.G. and D.F.; Data curation, C.Z., E.C., F.D. and D.F.; Formal analysis, C.Z., E.C. and F.D.; Funding acquisition, F.D. and U.G.; Investigation, C.Z., E.C., I.Z., G.C.V.V. and D.F.; Methodology, E.C., F.D., U.G. and D.F.; Project administration, F.D., U.G. and D.F.; Supervision, F.D., U.G. and D.F.; Validation, E.C., I.Z. and D.F.; Visualization, C.Z., E.C., I.Z., G.C.V.V., F.D. and U.G.; Writing-original draft, C.Z. and D.F.; Writing-review and editing, E.C., I.Z., G.C.V.V., F.D., U.G. and D.F. All authors have read and agreed to the published version of the manuscript.

Funding: The study was cofunded by the Research Centre Q-TECH Research and Study Centre (Quality and Technology Assessment, Governance and Communication Strategies in Health Systems), University of Brescia, and by the Lombardy Regional Authority which has provided a three-year research grant under agreements with the university for the promotion of research in the Lombardy region.

Conflicts of Interest: The authors declare no conflict of interest.

\section{References}

1. Pope, C.A., 3rd; Burnett, R.T.; Thun, M.J.; Calle, E.E.; Krewski, D.; Ito, K.; Thurston, G.D. Lung cancer, cardiopulmonary mortality, and long-term exposure to fine particulate air pollution. JAMA 2002, 287, 1132-1141. [CrossRef]

2. ERS. Air Quality and Health; European Respiratory Society: Lausanne, Switzerland, 2010. 
3. Janssen, N.A.; Fischer, P.; Marra, M.; Ameling, C.; Cassee, F.R. Short-term effects of PM2.5, PM10 and PM2.5-10 on daily mortality in the Netherlands. Sci. Total Environ. 2013, 463, 20-26. [CrossRef]

4. Raaschou-Nielsen, O.; Andersen, Z.J.; Beelen, R.; Samoli, E.; Stafoggia, M.; Weinmayr, G.; Hoffmann, B.; Fischer, P.; Nieuwenhuijsen, M.J.; Brunekreef, B.; et al. Air pollution and lung cancer incidence in 17 European cohorts: Prospective analyses from the European Study of Cohorts for Air Pollution Effects (ESCAPE). Lancet Oncol. 2013, 14, 813-822. [CrossRef]

5. Shah, A.S.; Langrish, J.P.; Nair, H.; McAllister, D.A.; Hunter, A.L.; Donaldson, K.; Newby, D.E.; Mills, N.L. Global association of air pollution and heart failure: A systematic review and meta-analysis. Lancet 2013, 382, 1039-1048. [CrossRef]

6. WHO. Evolution of WHO Air Quality Guidelines: Past, Present and Future; WHO Regional Office for Europe: Copenhagen, Danmark, 2017; pp. 1-39.

7. EAA. Air Quality in Europe-2019 Report; European Environment Agency, Technical report No 10/2019; Publications Office of the European Union: Luxembourg, 2019; pp. 1-99. [CrossRef]

8. Sørensen, M.; Autrup, H.; Møller, P.; Hertel, O.; Jensen, S.S.; Vinzents, P.; Knudsen, L.E.; Loft, S. Linking exposure to environmental pollutants with biological effects. Mutat. Res. 2003, 544, 255-271. [CrossRef] [PubMed]

9. Lewtas, J. Air pollution combustion emissions: Characterization of causative agents and mechanisms associated with cancer, reproductive, and cardiovascular effects. Mutat. Res. 2007, 636, 95-133. [CrossRef] [PubMed]

10. Anderson, J.O.; Thundiyil, J.G.; Stolbach, A. Clearing the air: A review of the effects of particulate matter air pollution on human health. J. Med. Toxicol. 2012, 8, 166-175. [CrossRef]

11. IARC. Outdoor air Pollution. IARC Monographs on the Evaluation of Carcinogenic Risks to Humans; International Agency for Research on Cancer: Albert Thomas, France, 2016; Volume 109, pp. 1-454.

12. Puett, R.C.; Hart, J.E.; Schwartz, J.; Hu, F.B.; Liese, A.D.; Laden, F. Are particulate matter exposures associated with risk of type 2 diabetes? Environ. Health Perspect. 2011, 119, 384-389. [CrossRef]

13. Balti, E.V.; Echouffo-Tcheugui, J.B.; Yako, Y.Y.; Kengne, A.P. Air pollution and risk of type 2 diabetes mellitus: A systematic review and meta-analysis. Diabetes Res. Clin. Pract. 2014, 106, 161-172. [CrossRef]

14. Bonassi, S.; Znaor, A.; Ceppi, M.; Lando, C.; Chang, W.P.; Holland, N.; Kirsch-Volders, M.; Zeiger, E.; Ban, S.; Barale, R.; et al. An increased micronucleus frequency in peripheral blood lymphocytes predicts the risk of cancer in humans. Carcinogenesis 2007, 28, 625-631. [CrossRef]

15. Bonassi, S.; Norppa, H.; Ceppi, M.; Strömberg, U.; Vermeulen, R.; Znaor, A.; Cebulska-Wasilewska, A.; Fabianova, E.; Fucic, A.; Gundy, S.; et al. Chromosomal aberration frequency in lymphocytes predicts the risk of cancer: Results from a pooled cohort study of 22358 subjects in 11 countries. Carcinogenesis 2008, 29, 1178-1183. [CrossRef] [PubMed]

16. Neri, M.; Ugolini, D.; Bonassi, S.; Fucic, A.; Holland, N.; Knudsen, L.E.; Srám, R.J.; Ceppi, M.; Bocchini, V.; Merlo, D.F. Children's exposure to environmental pollutants and biomarkers of genetic damage. II. Results of a comprehensive literature search and meta-analysis. Mutat. Res. 2006, 612, 14-39. [CrossRef] [PubMed]

17. Møller, P. The alkaline comet assay: Towards validation in biomonitoring of DNA damaging exposures. Basic Clin. Pharmacol. Toxicol. 2006, 98, 336-345. [CrossRef] [PubMed]

18. Hoffmann, H.; Speit, G. Assessment of DNA damage in peripheral blood of heavy smokers with the comet assay and the micronucleus test. Mutat. Res. 2005, 581, 105-114. [CrossRef] [PubMed]

19. Bonetta, S.; Bonetta, S.; Schilirò, T.; Ceretti, E.; Feretti, D.; Covolo, L.; Vannini, S.; Villarini, M.; Moretti, M.; Verani, M.; et al. Mutagenic and genotoxic effects induced by $\operatorname{PM}(0.5)$ of different Italian towns in human cells and bacteria: The MAPEC_LIFE study. Environ. Pollut. 2019, 245, 1124-1135. [CrossRef] [PubMed]

20. Ceretti, E.; Feretti, D.; Viola, G.C.; Zerbini, I.; Limina, R.M.; Zani, C.; Capelli, M.; Lamera, R.; Donato, F.; Gelatti, U. DNA damage in buccal mucosa cells of pre-school children exposed to high levels of urban air pollutants. PLoS ONE 2014, 9, e96524. [CrossRef]

21. de Brito, K.C.; de Lemos, C.T.; Rocha, J.A.; Mielli, A.C.; Matzenbacher, C.; Vargas, V.M. Comparative genotoxicity of airborne particulate matter (PM2.5) using Salmonella, plants and mammalian cells. Ecotoxicol. Environ. Saf. 2013, 94, 14-20. [CrossRef]

22. Dumax-Vorzet, A.F.; Tate, M.; Walmsley, R.; Elder, R.H.; Povey, A.C. Cytotoxicity and genotoxicity of urban particulate matter in mammalian cells. Mutagenesis 2015, 30, 621-633. [CrossRef]

23. Lemos, A.T.; Coronas, M.V.; Rocha, J.A.; Vargas, V.M. Mutagenicity of particulate matter fractions in areas under the impact of urban and industrial activities. Chemosphere 2012, 89, 1126-1134. [CrossRef] 
24. Szeto, Y.T.; Benzie, I.F.; Collins, A.R.; Choi, S.W.; Cheng, C.Y.; Yow, C.M.; Tse, M.M. A buccal cell model comet assay: Development and evaluation for human biomonitoring and nutritional studies. Mutat. Res. 2005, 578, 371-381. [CrossRef]

25. Pacini, S.; Giovannelli, L.; Gulisano, M.; Peruzzi, B.; Polli, G.; Boddi, V.; Ruggiero, M.; Bozzo, C.; Stomeo, F.; Fenu, G.; et al. Association between atmospheric ozone levels and damage to human nasal mucosa in Florence, Italy. Environ. Mol. Mutagen. 2003, 42, 127-135. [CrossRef] [PubMed]

26. Valverde, M.; del Carmen López, M.; López, I.; Sánchez, I.; Fortoul, T.I.; Ostrosky-Wegman, P.; Rojas, E. DNA damage in leukocytes and buccal and nasal epithelial cells of individuals exposed to air pollution in Mexico City. Environ. Mol. Mutagen. 1997, 30, 147-152. [CrossRef]

27. Dhawan, A.; Bajpayee, M.; Parmar, D. Comet assay: A reliable tool for the assessment of DNA damage in different models. Cell Biol. Toxicol. 2009, 25, 5-32. [CrossRef] [PubMed]

28. Collins, A.R.; Oscoz, A.A.; Brunborg, G.; Gaivão, I.; Giovannelli, L.; Kruszewski, M.; Smith, C.C.; Stetina, R. The comet assay: Topical issues. Mutagenesis 2008, 23, 143-151. [CrossRef]

29. Burlinson, B.; Tice, R.R.; Speit, G.; Agurell, E.; Brendler-Schwaab, S.Y.; Collins, A.R.; Escobar, P.; Honma, M.; Kumaravel, T.S.; Nakajima, M.; et al. Fourth International Workgroup on Genotoxicity testing: Results of the in vivo Comet assay workgroup. Mutat. Res. 2007, 627, 31-35. [CrossRef] [PubMed]

30. Fairbairn, D.W.; Olive, P.L.; O’Neill, K.L. The comet assay: A comprehensive review. Mutat. Res. 1995, 339, 37-59. [CrossRef]

31. Dietert, R.R.; Etzel, R.A.; Chen, D.; Halonen, M.; Holladay, S.D.; Jarabek, A.M.; Landreth, K.; Peden, D.B.; Pinkerton, K.; Smialowicz, R.J.; et al. Workshop to identify critical windows of exposure for children's health: Immune and respiratory systems work group summary. Environ. Health Persp. 2000, 108, 483-490. [CrossRef]

32. Rössner, P.; Bavorova, H.; Ocadlikova, D.; Svandova, E.; Sram, R.J. Chromosomal aberrations in peripheral lymphocytes of children as biomarkers of environmental exposure and life style. Toxicol. Lett. 2002, 134, 79-85. [CrossRef]

33. Chance, G.W.; Harmsen, E. Children are different: Environmental contaminants and children's health. Can. J. Public Health 1998, 89 (Suppl. 1), S9-S13.

34. WHO. Health Aspects of Air Pollution. Results from the WHO Project "Systematic Review of Health Aspects of Air Pollution in Europe"; WHO Regional Office for Europe: Copenhagen, Danmark, 2004; pp. 1-30.

35. Wild, C.P.; Kleinjans, J. Children and increased susceptibility to environmental carcinogens: Evidence or empathy? Cancer Epidemiol. Biomarkers Prev. 2003, 12, 1389-1394.

36. Holland, N.; Bolognesi, C.; Kirsch-Volders, M.; Bonassi, S.; Zeiger, E.; Knasmueller, S.; Fenech, M. The micronucleus assay in human buccal cells as a tool for biomonitoring DNA damage: The HUMN project perspective on current status and knowledge gaps. Mutat. Res. 2008, 659, 93-108. [CrossRef] [PubMed]

37. Cavalcante, D.N.; Sposito, J.C.; Crispim, B.D.; Nascimento, A.V.; Grisolia, A.B. Genotoxic and mutagenic effects of passive smoking and urban air pollutants in buccal mucosa cells of children enrolled in public school. Toxicol. Mech. Methods 2017, 27, 346-351. [CrossRef] [PubMed]

38. Villarini, M.; Levorato, S.; Salvatori, T.; Ceretti, E.; Bonetta, S.; Carducci, A.; Grassi, T.; Vannini, S.; Donato, F.; Bonetta, S.; et al. Buccal micronucleus cytome assay in primary school children: A descriptive analysis of the MAPEC_LIFE multicentre cohort study. Int. J. Hyg. Environ. Health 2018, 221, 883-892. [CrossRef] [PubMed]

39. Feretti, D.; Pedrazzani, R.; Ceretti, E.; Dal Grande, M.; Zerbini, I.; Viola, G.C.V.; Gelatti, U.; Donato, F.; Zani, C. "Risk is in the air": Polycyclic aromatic hydrocarbons, metals and mutagenicity of atmospheric particulate matter in a town of Northern Italy (Respira study). Mutat. Res. 2019, 842, 35-49. [CrossRef] [PubMed]

40. Holland, N.; Fucic, A.; Merlo, D.F.; Sram, R.; Kirsch-Volders, M. Micronuclei in neonates and children: Effects of environmental, genetic, demographic and disease variables. Mutagenesis 2011, 26, 51-56. [CrossRef] [PubMed]

41. Watters, J.L.; Satia, J.A.; Kupper, L.L.; Swenberg, J.A.; Schroeder, J.C.; Switzer, B.R. Associations of antioxidant nutrients and oxidative DNA damage in healthy African-American and White adults. Cancer Epidemiol. Biomarkers Prev. 2007, 16, 1428-1436. [CrossRef]

42. Osswald, K.; Mittas, A.; Glei, M.; Pool-Zobel, B.L. New revival of an old biomarker: Characterisation of buccal cells and determination of genetic damage in the isolated fraction of viable leucocytes. Mutat. Res. 2003, 544, 321-329. [CrossRef]

43. Singh, N.P.; McCoy, M.T.; Tice, R.R.; Schneider, E.L. A simple technique for quantitation of low levels of DNA damage in individual cells. Exp. Cell Res. 1988, 175, 184-191. [CrossRef] 
44. Silva da Silva, C.; Rossato, J.M.; Vaz Rocha, J.A.; Vargas, V.M. Characterization of an area of reference for inhalable particulate matter (PM2.5) associated wi thgenetic biomonitoring in children. Mutat. Res. 2015, 778, 44-55. [CrossRef]

45. Ceretti, E.; Zani, C.; Zerbini, I.; Viola, G.; Moretti, M.; Villarini, M.; Dominici, L.; Monarca, S.; Feretti, D. Monitoring of volatile and non-volatile urban air genotoxins using bacteria, human cells and plants. Chemosphere 2015, 120, 221-229. [CrossRef]

46. Calderon-Garcidueñas, L.; Osnaya-Brizuela, N.; Ramirez-Martinez, L.; Villarreal-Calderon, A. DNA strand breaks in human nasal respiratory epithelium are induced upon exposure to urban pollution. Environ. Health Perspect. 1996, 104, 160-168. [CrossRef] [PubMed]

47. Calderón-Garcidueñas, L.; Osnaya, N.; Rodríguez-Alcaraz, A.; Villarreal-Calderón, A. DNA damage in nasal respiratory epithelium from children exposed to urban pollution. Environ. Mol. Mutagen. 1997, 30, 11-20. [CrossRef]

48. Calderón-Garcidueñas, L.; Wen-Wang, L.; Zhang, Y.J.; Rodriguez-Alcaraz, A.; Osnaya, N.; Villarreal-Calderón, A.; Santella, R.M. 8-hydroxy-2'-deoxyguanosine, a major mutagenic oxidative DNA lesion, and DNA strand breaks in nasal respiratory epithelium of children exposed to urban pollution. Environ. Health Perspect. 1999, 107, 469-474. [CrossRef] [PubMed]

49. Ruchirawat, M.; Navasumrit, P.; Settachan, D.; Autrup, H. Environmental impacts on children's health in Southeast Asia: Genotoxic compounds in urban air. Ann. N. Y. Acad. Sci. 2006, 1076, 678-690. [CrossRef] [PubMed]

50. Tuntawiroon, J.; Mahidol, C.; Navasumrit, P.; Autrup, H.; Ruchirawat, M. Increased health risk in Bangkok children exposed to polycyclic aromatic hydrocarbons from traffic-related sources. Carcinogenesis 2007, 28, 816-822. [CrossRef] [PubMed]

51. Wilhelm, M.; Eberwein, G.; Hölzer, J.; Gladtke, D.; Angerer, J.; Marczynski, B.; Behrendt, H.; Ring, J.; Sugiri, D.; Ranft, U. Influence of industrial sources on children's health-hot spot studies in North Rhine Westphalia, Germany. Int. J. Hyg. Environ. Health 2007, 210, 591-599. [CrossRef]

52. Sánchez-Guerra, M.; Pelallo-Martínez, N.; Díaz-Barriga, F.; Rothenberg, S.J.; Hernández-Cadena, L.; Faugeron, S.; Oropeza-Hernández, L.F.; Guaderrama-Díaz, M.; Quintanilla-Vega, B. Environmental polycyclic aromatic hydrocarbon (PAH) exposure and DNA damage in Mexican children. Mutat. Res. 2012, 742, 66-71. [CrossRef]

53. Marcon, A.; Fracasso, M.E.; Marchetti, P.; Doria, D.; Girardi, P.; Guarda, L.; Pesce, G.; Pironi, V.; Ricci, P.; de Marco, R. Outdoor formaldehyde and NO2 exposures and markers of genotoxicity in children living near chipboard industries. Environ. Health Perspect. 2014, 122, 639-645. [CrossRef]

54. Coronas, M.V.; Rocha, J.A.; Salvadori, D.M.; Vargas, V.M. Evaluation of area contaminated by wood treatment activities: Genetic markers in the environment and in the child population. Chemosphere 2016, 144, 1207-1215. [CrossRef]

55. Ceppi, M.; Biasotti, B.; Fenech, M.; Bonassi, S. Human population studies with the exfoliated buccal micronucleus assay: Statistical and epidemiological issues. Mutat. Res. 2010, 705, 11-19. [CrossRef]

56. Corradi, M.; Poli, D.; Banda, I.; Bonini, S.; Mozzoni, P.; Pinelli, S.; Alinovi, R.; Andreoli, R.; Ampollini, L.; Casalini, A.; et al. Exhaled breath analysis in suspected cases of non-small-cell lung cancer: A cross-sectional study. J. Breath Res. 2015, 9, 027101. [CrossRef] [PubMed]

57. Bianchi, F.; Riboni, N.; Carbognani, P.; Gnetti, L.; Dalcanale, E.; Ampollini, L.; Careri, M. Solid-phase microextraction coupled to gas chromatography-mass spectrometry followed by multivariate data analysis for the identification of volatile organic compounds as possible biomarkers in lung cancer tissues. J. Pharm. Biomed. Anal. 2017, 146, 329-333. [CrossRef] [PubMed]

58. Ferraro, V.; Carraro, S.; Bozzetto, S.; Zanconato, S.; Baraldi, E. Exhaled biomarkers in childhood asthma: Old and new approaches. Asthma Res. Pract. 2018, 4, 9. [CrossRef] [PubMed]

59. Bannier, M.A.G.E.; Rosias, P.P.R.; Jöbsis, Q.; Dompeling, E. Exhaled Breath Condensate in Childhood Asthma: A Review and Current Perspective. Front. Pediatr. 2019, 7, 150. [CrossRef] [PubMed]

(C) 2020 by the authors. Licensee MDPI, Basel, Switzerland. This article is an open access article distributed under the terms and conditions of the Creative Commons Attribution (CC BY) license (http://creativecommons.org/licenses/by/4.0/). 